\title{
Micah True
}

Masters and Students. Jesuit Missionary Ethnography in Seventeenth-Century New

France. Montreal; Kingston: McGill-Queen's University Press, 2015. Pp. 242 pages.

$\mathrm{Pb}, \$ 32.95$ (CAD).

Micah True, an assistant professor in the Department of Modern Languages and Cultural Studies at the University of Alberta, has written an erudite study of the rhetorical strategies employed by Jesuit missionaries in New France between 1632 and 1673 in their famous "Jesuit Relations." True's strategy is to unsettle, if not deconstruct, what scholars think they know about the Relations, edited (and translated into English, often inaccurately, we are told) in seventythree volumes over a century ago by Reuben Gold Thwaites, and more recently published in an excellent French-language edition, Monumenta Novae Franciae (9 vols. [Rome: Institutum Historicum Societatis Iesu, 1967-2003]), by the late Lucien Campeau, S.J.

Scholars like myself (I have made use of the Jesuit Relations in producing a half-dozen books about American Indian encounters with Catholicism) have treated the published Jesuit writings as primary sources of knowledge about the early contacts between Amerindians and missionaries. The Jesuits observed the Algonkians, Iroquoians, and other Native peoples, attempted to learn their languages well enough to be able to communicate sophisticated theological ideas, and scrutinized their own preconceptions and methods of proselytizing. Each Jesuit wrote letters to the mission superior (for many years Paul Le Jeune), who collated and edited the missives, introduced them with his own words, and sent them to France, where they were further modified and published for the edification of the reading public, including those whose political and financial support was crucial to the mission enterprise. Despite suspicion about the cultural and religious biases of the missionaries, scholars have relied on the Relations as the major source of information about Native cultures at the time of first contact, and the nature of the interplay between French invaders and indigenous peoples of North America. After all, for all their prejudices, the Jesuits were there; they were primary actors and self-aware describers of the contact. In a sense they were ethnographers, steeped in participantobserver methodology worthy of our trust.

True's book aims to "give pause" (168) to scholarly trust in the Relations, to "undermine" (169) their long-held authority and claims to accuracy. He reminds us that we have precious few of the original, hand-written Jesuit letters, and when we are able to compare a manuscript with its published version, we find some significant changes made by the redactors in Paris. As for the missionaries' heralded linguistic prowess, True recalls the "poor use of Amerindian lan- 
guages" (42) in the 1600 s, which "drew ridicule from potential converts and allowed the missionaries' religious message to be easily brushed aside" (42).

Indeed, as much as the Jesuits have been considered linguistic "masters," in their relationship to indigenous speakers, they were mere "students" - hence the book's title. Nonetheless, these learners, both humble and haughty, felt that they could discern what was "rich" and "poor" (57) in Amerindian languages: rich in their beauty and complexity, but poor in their familiarity with Christian and Eurocentric concepts. Thus, as presented to their French readers, the Jesuits depicted Indians as a) eminently capable of learning the true faith, but b) presently deficient in salvific wherewithal - the two vectors of justification for missions. Even in their ritual cruelty, the Iroquoians (made infamous by the Jesuits) were portrayed as rational, albeit barbarous, and when they converted to Christianity, they were capable of heroic imitations of Christ's passion under grisly torture at the hands of their Native enemies.

In their writings, the Jesuits wondered "how Amerindians were related to the rest of known humanity" (115) — created by the one God of Christian cosmology - and how Native myths portrayed the origins of the universe. Le Jeune, for one, found "true, if distorted knowledge of Genesis" (124) in Montagnais myths, however "corrupted with silly stories" (124). Le Jeune could not help but hold his own worldview as the truth, and theirs as nonsense. At the same time he conflated his own God as "first author' of the world" (136) with the mythological trickster-transformer and with the very "act of telling stories" (133), thereby obscuring more than clarifying any edifying comparison of Western and Native narrative traditions.

In the end, True poses the question of Jesuits' accuracy as ethnographers: how did they "perceive Amerindian cultures and represent them for the benefit of readers?" (173). How was their observational rhetoric "influenced by their simultaneous religious mission?" (173). True's nuanced answers to these questions, which constitute the whole of his book, do not overturn scholarly appreciation of the Jesuits' witness to their own transforming incursion to Native American life. We shall keep returning to the Jesuit Relations as our own teachers when we wish to learn about the Indians impinged by colonialism in New France. They may be flawed sources, yet they are incomparable in value. Nevertheless, True's critical discernments do justice to the complexities of the spiritual encounter of the seventeenth century.

\footnotetext{
Christopher Vecsey

Colgate University

cvecsey@colgate.edu

DOI 10.1163/22141332-00301005-21
} 